Interdisciplinary Studies of Complex Systems

No. 15 (2019) 128-144

(c) I. Грабовська

https://doi.org/10.31392/iscs.2019.15.128

\title{
ФЕНОМЕН АКАДЕМІЧНОГО ПЛАГІАТУ В СУЧАСНІЙ УКРАЇНІ: ПРИЧИНИ ІСНУВАННЯ ТА ПЕРСПЕКТИВИ ПОДОЛАННЯ
}

\author{
Ірина Грабовсъка ${ }^{1}$
}

\begin{abstract}
Анотація. Аналізуються причини значного поширення академічного плагіату в сучасній українській науці. Акцентовано увагу на розповсюдженні цього феномена у світовій науці. Проведено історичні паралелі при вивченні феномена плагіату. Зосереджено увагу на специфіці української ситуації із плагіатуванням. Розглянуто два радикально протилежні підходи у боротьбі із плагіатом. Доводиться, що проблема академічного плагіату, як і плагіатування у інших сферах діяльності, не зводиться лише до етико-моральних характеристик суб'єктів наукових інституцій, а має соціальний характер і напряму залежить від загальної ситуації в країні, а також і від ціннісно-світоглядних, філософських, навіть ментальних особливостей спільноти загалом та наукової спільноти як її частини.
\end{abstract}

Ключові слова: Україна, академічний плагіат, наукова спільнота, світова наука, антиплагіат.

\section{PHENOMENON OF ACADEMIC PLAGIARISM IN MODERN UKRAINE: CAUSES OF EXISTENCE AND PERSPECTIVES OF SUBMISSION}

\author{
Iryna Grabovska
}

\begin{abstract}
The article analyzes the reasons for the significant spread of academic plagiarism in modern Ukrainian science. The emphasis is on the dissemination of this phenomenon in world science. The author carries out historical parallels in studying the phenomenon of plagiarism. The attention is focused on the specifics of the Ukrainian plagiarism situation and two radically opposite approaches are being considered in the fight against plagiarism. The article shows that the problem of academic plagiarism, as well as plagiarism in other spheres of activity, is not limited to the ethical and moral characteristics of the subjects of scientific institutions, but has a social character and direction depends on the general situation in the country, as well as on the value-ideological, philosophical, even mental features of the community as a whole and the scientific community as a part of it.
\end{abstract}

Keywords: placecountry-regionUkraine, academic plagiarism, scientific community, world science, anti-plagiarism.

\footnotetext{
${ }^{1}$ Філософський факультет, Центр українознавства, Київський національний університет імені Тараса Шевченка. grabovskai@ukr.net, https://orcid.org/0000-0002-7416-9541.
} 


\section{Вступ}

Проблема плагіату та боротьби із ним в Україні регулярно загострюється. Останній конфлікт пов'язаний із гострою реакцією та публічним виступом відомої літературознавиці та член-кореспондента Академії Наук України Т. Гундорової з приводу виявленого плагіату в роботі Д. Дроздовського, яка подавалась на захист для отримання докторського ступеню з літературознавства [1]. Як зазначалося сайтом «ЛітАкцент» «Група з чотирьох експертів-філологів підготувала висновок стосовно нецитованих запозичень у монографії «Множинність реальності в англійському постмодерністському романі» докторанта Інституту літератури ім. Т. Шевченка та відомого літературознавця Дмитра Дроздовського» [1].

Обговорення вказаної події набуло широкого розголосу у кулуарах українських академічних установ та вузів, соціальній мережі Фейсбук та у низці українських 3MI, і знову показало, якою злободенною та масштабною є проблема академічного плагіату в Україні. На форумі сайту «ЛітАкцент» пані Т. Гундорова прокоментувала ситуацію довкола вказаного випадку: «е той випадок, коли псевдонаука в Україні досягла таких масштабів і стала такою безцеремонно цинічною, що мовчати про це вже просто не можна. Якщо ми пробачаємо цей плагіат, ми підписуємося під тим, що вся гуманітаристика в Україні є псевдонаукою». Щоправда, наостанок науковиця додала: «Я вірю, що це не так» [1].

Варто зазначити, що плагіат - це не лише «хвороба» сучасної української науки. Вона має глибоке коріння в минулому і тією чи іншою мірою притаманна усій світовій науці [Див., напр. 2; 3]. «Гадаю, ми мусимо сьогодні відверто говорити про явища, котрі вже почали узвичаюватися в Європі, зокрема в Україні, - про витіснення дослідницьких стратегій гуманітарної науки стратегіями волі до влади, боротьбою за знаки престижу, про створення корпорацій імітаторів з жорсткою авторитарною структурою, про знецінення самодостатності наукового пошуку, про радикальне звуження зони академічної свободи» $[4,102],-$ аналізує реальну ситуацію дослідниця Н. Корнієнко у статті «Імітація і плагіат як загроза академічній свободі». I з таким баченням варто погодитись, адже вже багато років поспіль на всьому пострадянському просторі відбуваються процеси, які самим фактом своєї наявності руйнують науку і як суспільний інститут, і як сферу незалежного пізнавального пошуку. Мова йде насамперед про «написання» та захист дисертацій як рівня кандидатів наук, так і докторських представниками владних структур України - депутатами різних рівнів та чиновниками. А якщо додати до цього ще й масове плагіатування, а фактично, крадіжку чужих текстів, починаючи від шкільних рефератів до студентських робіт різного рівня складності та кваліфікаційної відповідності, то можна стверджувати, що вище вказані процеси вже набули катастрофічних розмірів. Вказані вище явища також стали масштабними на усьому пострадянському просторі. На жаль, Україна у цьому процесі не лише не є винятком, але й займає не останні місця. Проте, проблема набула глобального масштабу. Ї̈̈ загрозу засвідчують і науковці так званого цивілізованого світу. Про це йдеться, наприклад, у статті М. Ф. Абад-Гарсії «Плагіат та хижі журнали: загроза науковій цілісності» [3]. 
За визначенням, яке дається у популярній енциклопедії «Вікіпедія», під поняттям «плагіат» розуміємо «... привласнення авторства на чужий твір або на чуже відкриття, винахід чи раціоналізаторську пропозицію, а також використання у своїх працях чужого твору без посилання на автора» [5].

У свою чергу авторки статті «Політика України щодо плагіату» Н. Гриценко та Л. Присяжна зазначають, що «Вікіпедія наводить визначення поняття "плагіат", запропоноване авторами програмного забезпечення Turnitin $з$ доступом через веб-сайт як «вкрасти ідею або слова іншої людини і видати їх за власні; використати результати роботи іншої людини без вказання джерела, звідки вони були взяті; повністю або частково вкрасти мистецький, науковий або інший твір чи роботу та видати їх за свою; представити вже існуючу ідею або продукт як новий та оригінальний» [6].

Пошук «коріння» плагіату та мотивацій процесу привласнення чужого наукового доробку та ідей $є$ не лише актуальною, але й нагальною проблемою сучасної української науки, як і боротьба із цим ганебним явищем. Отже, метою даної розвідки є спроба розставити акценти у розумінні сутності плагіату як явища, а також з'ясувати причини, що породжують феномен плагіату в українській науці сьогодні, що, у свою чергу, допоможе виявити найперспективніші шляхи боротьби із ним. При цьому варто дослухатись до думки про те, що для сучасних українців «є вкрай важливим у публічному діалозі відстежувати не лише, сказати б, академічний мейнстрим, а й тривожні тенденції, що намітилися в сучасному науковому дискурсі. Уникнувши надмірностей непродуктивних дискусій, варто зосередитися на проблемах, які вже сьогодні загрожують незворотними наслідками для науки в цілому. Понад те, байдужість наукового середовища мимоволі може стати плідним грунтом для усталення небезпечних тенденцій, для руйнування академічної свободи як засадової цінності громадянського суспільства» $[4,109]$.

\section{Виклад основного матеріалу}

Історія плагіату та ставлення до нього нараховує століття і навіть тисячоліття. Науковці Іш Кумар Дхаммі та Рехан Уль Хак, стверджують, що до Оксфордського словника англійської мови слово «плагіат» потрапило у 1621 р. А «Британська енциклопедія» визначила сутність плагіату як акт присвоєння чужого твору та видання його за власний [2]. У більшості широковідомих текстів із цієї проблеми наводиться приклад, що вже Платона звинувачували у плагіаті. Українці теж мають широковідомі істоpiї списування чужих текстів, які нараховують вже не одне десятиліття. Так, наприклад, часто описується випадок із творчого життя М. Вовчок. «Марко Вовчок протягом 1870-1872 років публікувала в петербурзькому місячнику «Переводы лучших иностранных писателей» переклади російською, зроблені найнятими нею людьми, під власним прізвищем. Пізніше одна з цих наймичок підсунула Вовчок переклад казок Андерсена, який насправді просто списала зі зробленого два роки тому перекладу кількома іншими перекладачками. Казки вийшли друком, а справжні автори перекладів здійняли галас. В результаті, третейський суд з 19 літераторів 
визнав Вовчок винною у плагіаті. Зізнатися в тому, що насправді твори вкрала не вона, письменниця не могла. Адже тоді б з'ясувалося ще й те, що вона таємно наймала перекладачок і їхні роботи підписувала власним прізвищем» [5].

Авторка цієї статті спеціально частково послуговується відомими та доступними фактично кожному джерелами для того, щоб підкреслити розповсюдженість та «зрозумілість» широкому загалові проблеми, яка аналізується.

Філософській спільноті також добре відомий факт звинувачення Нiколая Бердяєва у плагіаті ідей Ніцше, якого Бердяєв глибоко поціновував, та особливо у самоплагіаті. Щоправда, останньому закидові відомий філософ не надавав серйозного значення, стверджуючи, що постійно мислячій особистості, яка об'єктивує в культурі свої розмисли у вигляді текстів, неминуче будуть притаманні самоповтори. I в цьому немає нічого страшного, це лише закріплює думку мислителя та вводить її різними шляхами в культурний контекст. Вочевидь, у таких доводах філософа є раціональне зерно. Адже відомо, що думка починає функціонувати в культурі та набуває певної цінності, якщо вона повторюється у різних варіаціях принаймні п'ять разів. Тому є доцільним, щоб кожен вчений, особливо вчений-гуманітарій повинен окрім суто наукових публікацій у фахових академічних виданнях займатись популяризацією власних досліджень, повторюючи у них у більш доступній для широкого загалу формі думки та розмисли, викладені у суто академічних текстах. Інакше наука фактично буде займатись самоізоляцією, а ідеї, вже колись відкриті та доведені, - перевідкриватись і доводитись заново. Проте, це вже тема окремого аналітичного розмислу, як і тема самоплагіату, яка, вочевидь, є окремим напрямком у вивченні феномена плагіату. У даному випадку мова йде саме про академічний плагіат, який на сьогодні найпростіше визначити та «ввести в межі», бо проблема плагіату чи мімесису, наприклад, у мистецтві має принципово іншу природу, ніж у науці, і не вирішується способом прийняття закону з цього приводу, як би добре він не був виписаний.

У наукових зарубіжних дослідженнях, присвячених проблемі академічного плагіату, пропонується класифікація плагіату за певними характеристиками: 1) дослівний плагіат передбачає дослівне використання чужого тексту без посилання на автора; 2) мозаїчний плагіат, при застосуванні якого використовуються вперемішку власні слова та ідеї із чужими без посилання на джерело; 3) перефразування, коли частина тексту переписується своїми словами, але сутність залишається запозиченою із відсутністю посилання на автора та початковий текст; 4) самоплагіат, під яким розуміється широкий спектр дій - від самокопіювання текстів та ідей з подальшою їх повторною публікацією, до використання часткових само повторів у вигляді окремих частин текстів чи їхньої комбінації без посилання на першоджерела [2].

Станом на сьогодні в науковій аналітиці, де йдеться про плагіат, існує принаймні дві радикально протилежні позиції, як, зрештою, і у ставленні до цього явища у науковому середовищі України загалом. Одна полягає у розумінні явища академічного плагіату як етико-моральної проблеми наукового середовища і зводиться до визначення плагіату як списування 
текстів (насамперед) іншого вченого та присвоєння його ідей і видавання ïx за свої. I таке розуміння найбільш точно співпадає із Законом України «Про авторське право і суміжні права», остання редакція якого відбулася у листопаді 2018 р. [7], а також із Законом України «Про освіту». У статті 42, пункті 4 цього документу дається визначення академічного плагіату, під яким розуміється «оприлюднення (частково або повністю) наукових (творчих) результатів, отриманих іншими особами, як результатів власного дослідження (творчості) та/або відтворення опублікованих текстів (оприлюднених творів мистецтва) інших авторів без зазначення авторства».

Виникнення та масове поширення плагіату в сучасній Україні часто пояснюється падінням етико-моральних принципів існування наукових спільнот. Як вважає дослідник О. Хома, пов'язування причин поширення академічного плагіату в Україні загальними негараздами її розвитку невиправдано. «... зазначені негаразди мають, так би мовити, зовнішнє походження. Вони впливають на наукові спільноти, але виникли поза їхніми межами. Однак існує низка, так би мовити, «ендогенних» проблем, за які відповідальні лише самі ці спільноти, хай би як несприятливо складалася зовнішня кон'юнктура. Йдеться про небачені раніше масштаби плагіату i псевдонауки, що стали наслідком істотної моральної кризи самих наукових спільнот. Цю кризу не можна списати, скажімо, на «недостатнє фінансування», бо реакцій на економічні проблеми може бути багато, і немає жодної неминучості в тому, щоби втрачати моральні орієнтири» $[8,47]$.

Частково із наведеною думкою можна згодитися, але лише частково. Бо процес комерціалізації науки, який охопив увесь так званий цивілізований світ, зачепив і Україну. «Напевне, вже настав час говорити вголос про найболючішу проблему інтелектуального поля України - про паранауку, плагіат, практичну відсутність сучасних, новітніх методологій на наших теренах, про маніпулятивні технології, про загрозливі симулякри та фікції в науці тощо, - зазначає Н. Корнієнко, - адже процеси уніщовлення самої суті науки в цій сфері здатні знищити провідні, фундаментальні цінності громадянського суспільства (і вже знищують). Отже, по кому подзвін?» 3 дослідницею не можна не погодитись у тому, що «особливо ураженою є гуманітарна сфера. Адже саме на неї лягає нині тягар відповідальності за наближення суспільства до сучасної ноосфери саме через прогрес у гуманітарній царині радикально змінилися цивілізаційні процеси в Європі та світі за останні 40 років». I далі авторка статті «Імітація і плагіат як загроза академічній свободі» Н. Корнієнко зазначає: «У даному випадку я не беру на себе ризик говорити про весь заявлений спектр проблем. Але треба нарешті розпочати серйозну розмову про ці небезпечні процеси. Тим паче, що вони є відгомоном ще однієї проблеми, не менш актуальної й загрозливої проблеми драматичного конфлікту, сказати б, двох етичних цивілізацій. Цивілізації конс'юмеристської, прагматичноспоживацької, «кар'єрно-спринтерської», з анігільованими етичними цінностями, із заміщенням креативно-гуманістичних картин світу маргінальними, картинами глобального мегамаркету, де товаром виступає геть усе, з одного боку, а з іншого - цивілізації з культурою відповідальності, культурою Провини і Сорому, де перевагу віддано цінностям, які не можуть стати товаром...» $[4,102]$. 
Вочевидь, ситуація у науковому світі так званих цивілізованих країн дає підстави для «звинувачення» філософії конс'юмеризму у негараздах академічного середовища. Адже навіть такі розвинені та «законослухняні» країни, як Великобританія та Німеччина, де існують серйозні механізми боротьби із академічним плагіатом, все ж не можуть похизуватися його відсутністю. «За результатами дослідження німецьких соціологів, в Німеччині $50 \%$ наукових робіт містять плагіат. Не менше негативу в науковому середовищі Великобританії, де з плагіатом стикаються $58 \%$ університетських викладачів» $[9,6]$.

Причин розповсюдження плагіату чимало. I серед них одна із основних пов'язана «зі стрімким нагромадженням «гуглової» інформації в одиницю умовного часу, яку неспроможний охопити мозок (ти маєш бути чи не енциклопедистом-універсалом сучасності, щоб «вихопити» плагіат зі стрімкого інформаційного потоку), - зазначає Н. Корнієнко. - До цього треба додати брак поваги до найскладнішої сфери інтелектуального пізнання і самопізнання - фундаментальної науки, що засвідчує своєрідну ентропію суспільної свідомості, знищення системи мотивацій для науковця» $[4$, 108].

При виключно етико-моральному підході до розуміння проблеми плагіату все зрештою впирається у відповідальність самих науковців та їхню здатність протистояти конс'юмеристським настроям у власному соціумі. I тоді головним має бути не покарання за плагіат, а створення у академічному середовищі нетерпимості до можливості існування явища списування чужих робіт та привласнення чужих ідей. Свого часу такі думки висловлював колишній міністр Міністерства освіти та науки С. Квіт. Ідеї створення клімату нетерпимості щодо плагіату у наукових колективах активно висловлювались та висловлюються і сьогодні як самими науковцями, так i керівництвом наукової галузі. Та це не виключає існування покарання за плагіат [6].

Друга із двох радикально протилежних позицій щодо плагіату полягає у тому, що навіть керуючись таким обмеженим та вкрай конкретизованим розумінням, як у існуючих законах, плагіат неможливо подолати, бо це явище вічне, як наприклад, вічна в історії людства найдревніша професія. Боротися з таким явищем потрібно, оскільки воно руйнує насамперед морально-етичні засади функціонування науки як певного суспільного організму та інституції, але очікувати радикальних змін (наприклад, повного зникнення такого явища, як плагіат) не випадає. Цей феномен має глибоке соціальне коріння і тому в принципі неподоланний як факт. Його потрібно розглядати як соціальне зло, яке має своє виправдання навіть на рівні світоглядних та філософських установок спільноти. Мова йде не лише про філософію конс'юмеризму, а стосовно України, де більшість населення належить до малозабезпечених верств, насправді не випадає вважати, що саме вказана філософія найбільше впливає на українців в основній масі та саме вона породжує вказані негативні явища в науці. Скоріше, на виникнення та стійкість подібних негативних проявів в науці України активно впливає загальна світоглядна криза постколоніального соціуму, яка бере свій початок у «лихих дев'яностих». Саме «завдячуючи» періодові «первинного накопичення капіталу» початку $90-\mathrm{x}$, коли почало формуватися масове 
усвідомлення того, що у цьому суспільстві той, хто не може добитись успіху (під яким розумілось накопичення матеріального багатства) будь-яким шляхом та способом, частіше за все - шляхом кримінальних оборудок, та ще й отримати за таке «вміння» усю повноту влади у державі, стає невдахою, «лузером», тим, хто «не вміє жити». Масова свідомість пострадянського суспільства в Україні сприйняла такий стан справ як життєву реальність і значною мірою толерувала її. Подібні світоглядні установки, накладаючись на тотальне недотримання законів, усталили не лише плагіат, але й корупцію та інші зловживання у ВНЗ та академічних установах. Тоді ж виникло і набуває розмаху явище «науковця-імітатора». Дослідниця Н. Корнієнко аналізує: ««Новатор-перевертень» - це явище останніх двадцяти років, що квітне й досі. Симуляція в науці - це міна уповільненої дії. «Учені-імітатори» вже «під себе» обирають учнів, колег, створюють кафедри, інститути, лабораторії, відділи, «зачищуючи» територію науки й наукове середовище під диктатуру симулякра. Власне, це вже й відбувається, навіть у поважних національних академіях. Так блокуються шляхи до науки ученим-новаторам. I може так статися, що за якийсь час ентропія знищить інтелектуальний потенціал суспільства, остаточно зруйнує креативне середовище. Наслідки будуть катастрофічні. А такі сьогоденні інволюційні рухи в культурі лише посилюють небезпеку. ...у європейських демократіях просто неможлива за визначенням ситуація, коли плагіат залишається безкарним, не викликає належної суспільної реакції. У нас же плагіат часто-густо перетворюється на індустрію. Схоже, суспільство вже втрачає механізми самозахисту і критичну масу» $[4,105]$.

Прихильники розуміння плагіату як, насамперед, соціальної проблеми вважають, що процес боротьби із цим явищем не матиме особливої ефективності, якщо не відбуватиметься паралельно із оздоровленням усього соціального організму загалом. Тому і до завдання подолання плагіатування в науці потрібно підходити комплексно, паралельно вирішуючи і питання корупції, симуляції, псевдо науковості тощо. Варто розуміти, що для України це завдання на довгі роки.

Натомість, науковці, які дотримуються так званої «етико-моральної позиції в науці» у питаннях плагіатування, як правило вважають, що подолати таке ганебне явище, як плагіат в сучасній українській науці можна за допомогою систем перевірки текстів на плагіат типу «Антиплагіат» та посиленням покарань за виявлені факти плагіату. Зрештою, на сьогодні Україна вже має певний досвід боротьби із явищем плагіатування, застосовуються спеціальні комп'ютерні програми для його виявлення, створено непогану законодавчу базу з цього питання, існують громадянські ініціативи у боротьбі із ним: від персональної активності окремих свідомих громадян до створення незалежних громадських організацій, чия діяльність спрямована на виявлення академічного плагіату та боротьбу із ним. $\mathrm{y}$ науковій літературі зроблений непоганий порівняльний аналіз задіяних на сьогодні антиплагіатних комп'ютерних програм у МОН та низці ВНЗ України, частина з яких є власне українськими розробками [9].

Усі ці механізми вже активно задіюються, але немає принципових змін. Отже, вирішення проблеми подолання плагіату не лежить на поверхні, хоча методи, які вже застосовуються, теж дають свій частковий 
результат. Але покладатись лише на совість науковців та існуючі засоби контролю за плагіатом - це, вочевидь, означає не розуміти усієї глибини проблеми і будувати явно утопічні проекти його повного подолання.

Спроба поставити науку в Україні на комерційну основу при відсутності прозорих «правил гри», тотального недотримання спільнотою законів загалом, призвела до цілої низки зловживань. I плагіат є лише вершиною айсбергу негараздів, які притаманні сучасній українській науці як соціальному інститутові та сегментові суспільного буття українців. Тому більш переконливою є думка Ю.Н. Харарі, ніж наведена у статті О. Хоми «Еективний опір науковця за умов морального розпаду наукових спільнот». Ю. Н. Харарі зазначає: «Ми живемо в добу техніки. Багато людей переконані, що наука і техніка мають відповіді на всі наші проблеми. Нам лише слід дозволити науковцям та технікам продовжити їхню роботу, і вони створять рай на Землі. Але ж наука - не якесь особливе підприємство, що в моральному чи духовному плані вище за решту людської діяльності. Як і всі інші частини нашої культури, вона формується економічними, політичними та релігійними інтересами. При цьому наука - дуже дороге заняття» $[10,339]$. Отже, і вимагати від науки якоїсь «особливої чистоти» та моральності, особливо у кризовому соціумі, було б принаймні, нерозумно. Бо це б означало одразу запрограмувати себе на поразку у боротьбі з існуючими негараздами. Криза в академічному середовищі України є системною і так само системно іiї потрібно долати. I лише в такому разі можна буде говорити, що «... реакцій на економічні проблеми може бути багато, і немає жодної неминучості в тому, щоби втрачати моральні орієнтири» $[8,47]$.

Визнаючи, що наука як суспільний інститут нічим не краща від інших інститутів держави і так само реагує на всі тенденції та трансформації, які відбуваються у соціумі, очікувати ефективності у боротьбі із їі проблемами варто лише у разі «оздоровлення» всього суспільного організму. А в українському соціумі протягом попередніх років склалася система купівлі/продажу цілої низки послуг, які в принципі несумісні із поняттям наукової добросовісності та професійної чесності. До таких належать: замовлення усіх типів наукових робіт «під ключ» за гроші, часто, дуже значні. Такий вид пропозицій «на ринку наукових послуг» включає, наприклад, як написання реферату, наукової статті, курсової студентської роботи, так i дипломної кваліфікаційної роботи. Не кажучи вже про надзвичайно поширену практику написання «під ключ» кандидатських та докторських дисертацій, що напряму пов'язано із процвітанням корупції та інших зловживань в науковому середовищі країни [Див., напр.: 11].

Часто при написанні подібних «наукових» досліджень виконавці вдаються до плагіату навіть у найгрубішій його формі. Під «самостійною» роботою та «оригінальним» текстом виявляються переклади із іншомовних джерел: статей, дисертацій, навіть студентських рефератів, які безсоромно видаються за автентичну авторську розробку. Широко використовувались і списування із вітчизняних дипломних, кандидатських та докторських дисертацій у попередні роки в Україні. Цей «поживний субстрат» дещо скоротився із розповсюдженням Інтернету, оприлюдненням наукових досліджень у глобальній мережі, введенням спеціальних антиплагіатних заходів 
з боку МОН та вчених рад університетів. Але вважати, що ці міри повністю заблокували списування із вітчизняних та зарубіжних джерел було б помилковим. I це не поодинокі випадки. Варто лише відкрити статтю про плагіат у Вікіпедії, щоб ознайомитись із широковідомими фактами плагіатування, здійсненими як людьми від політики, так і суб'єктами від науки як у зарубіжних наукових колективах, так і в українських [5].

Абсолютно зрозуміло, чому «процвітає» плагіат у роботах, виконаних на замовлення. Адже неможливо провести дійсно самостійне і глибоке дослідження у будь-якій галузі наукового пізнання у визначені замовникомплатником терміни. Вище наведені факти широко відомі українській спільноті. Як правило, приклади плагіату, які обговорювались у пресі, підтверджуються стовідсотково. Проте, прикладів покарання через суди, навіть позовів по абсолютній більшості відомих фактів плагіатування ми сьогодні не маємо. Як не маємо і позовів з боку тих, чиї роботи були просто вкрадені таким відверто цинічним способом. Це неважко підтвердити, аналізуючи навіть найвідоміші та зафіксовані неодноразово факти. Візьмімо приклади, наведені тією ж енциклопедією Вікіпедією, матеріали якої часто використовуються і широко відомі найширшому загалові українців. По більшості наведених у статті «Плагіат» фактів списування позовів не було, як не було і позовів про захист авторитету тих, кого публічно звинувачують у плагіатуванні. А між тим у сучасній Україні існує ціла низка законів, спрямованих на захист від плагіату та плагіаторів. Т. Коваленко зазначає: «Відповідно до ст. 432 ЦК України, кожна особа має право звернутися до суду за захистом свого права інтелектуальної власності відповідно до ст. 16 ЦК України («Захист цивільних прав та інтересів судом»)» $[12,36]$. Існує три типи відповідальності за це «інтелектуальне мародерство». Осудним за плагіатування може бути особа у відповідності до кримінального, адміністративного та цивільного кодексів України. Так, «відповідно до ст. 439 Цивільного кодексу України ... автор має право протидіяти будь-якому перекрученню, спотворенню чи іншій зміні твору або будь-якому іншому посяганню на твір, що може зашкодити честі та репутації автора»,- зазначається у розвідці Т. Коваленко «Плагіат: види та відповідальність» $[12,36]$.

Адміністративний кодекс України передбачає адміністративну відповідальність за факт виявленого плагіату у вигляді штрафу у відповідності до ст. 51-2, у якій йдеться про адміністративні порушення за незаконне використання об'єкта права інтелектуальної власності.

Кримінальним кодексом України також передбачено кримінальну відповідальність за плагіат статтею 176. При кримінальній відповідальності за плагіатування передбачено навіть покарання у вигляді позбавлення волі від двох до п'яти років у залежності від розмірів нанесеного морального та матеріального збитку.

Не потрібно окремо доводити, що науковці добре ознайомлені з існуванням вище наведених законних засобів боротьби проти плагіату та плагіаторів. Відсутність судових позовів в Україні з приводу плагіатування вказує, на жаль, не на відсутність плагіату (його масштаби величезні!), а на примирливе ставлення академічної спільноти до цього справді ганебного явища. 
Отже, наукова громадськість сучасної України принаймні частково «поблажливо» ставиться до вказаного явища. Доводиться констатувати, що і сучасний український соціум в цілому добре ознайомлений із наявністю проблеми плагіату в науці i, як показує життя, досить толерантно ставиться до неї. Виникає запитання: «Чому це так?» Чимало із тих науковців, із ким авторці доводилось обговорювати проблеми плагіату в українській науці, вказують саме на загальний стан української дійсності чи й напряму проговорюють неможливість подолання плагіатування в умовах існування ринкового попиту на такий вид «товару», як наукова робота під замовлення. Адже попит породжує пропозицію. До того ж відомо, що закони в Україні не виконуються. Закон про покарання навіть позбавленням волі за написання за гроші дисертацій, як показує реальна практика, нікого не зупинив на цьому ринкові послуг. Як і раніше, фактично кожен із діючих наукових співробітників певним чином відслідковується такими «бізнес-структурами» і отримує навіть на власну електронну пошту запрошення до «співпраці» у вигляді цілком конкретних пропозицій. Особливої актуальності в останні роки набула пропозиція створення «під ключ» статей до двох наукометричних світових баз Scopus та Web of Sience. Цей вид «наукової» діяльності набуває справді глобальних масштабів. I «ціна питання» при такій пропозиції часто просто астрономічна для українських науковців. Здавалось би вихід очевидний: пишіть самі. Проте, і на такі «дорогі» пропозиції існує попит в Україні. Інакше, за логікою, такі бізнеспроекти просто зникли б. Натомість, число пропозицій від різних «фірм» зростає. Щоб не бути голослівною, авторка наведе приклад із власного досвіду. Запрошення «до співпраці», а вірніше, стати «законним плагіатором» прийшло просто на приватну електронну адресу. Саме плагіатором, бо як інакше розцінити пропозицію наступного гатунку (подається мовою оригіналу): «...Если же готовой научной статьи еще нет «Научные публикации - Publ.Science» предлагает возможность опубликоваться в соавторстве с учеными, в уже готовой к публикации статье в Scopus или Web of Science. Компания «Научные публикации - Publ.Science» поможет в поиске соавторов, как для тех, кто хочет приложить свои усилия и знания в исследовании вместе с другим автором, так и для ученых, не имеющих собственного научного труда, но желающих получить публикацию. Все что для этого нужно - обратиться к нашим специалистам, которые в короткие сроки подберут Вам подходящего соавтора». I далі: «Наша компания (Научные публикации - Publ.Science) учитывает все выше названные запросы. Мы помогаем найти соавторов для ученых, которые только хотят издаваться или уже имеют статьи в WoS или Scopus. Согласитесь, что это хорошее решение сотрудничать с одним или несколькими исследователями, когда мало времени для написания работы или нет необходимой суммы для услуг на публикацию под ключ» [13].

При цьому надаються гарантії «успіху». Інакше, ніж міжнародним бізнес-проектом або бізнес-аферою від науки це не можна назвати. При цьому як позитив наводиться інформація про те, що «нам все больше поступают заявки на поиск соавторов для издания статей в БД Scopus или WoS. И мы успешно находим ученых для сотрудничества. . . . Наш многолетний опыт и профессионализм в области научных публикаций гарантирует 
успешное сотрудничество со всеми нашими авторами». При цьому «связаться с нами Вы можете любым удобным способом...» [13].

Вище наведені факти - це незавуальована пропозиція проплатити процес плагіатування та яскравий приклад псевдонауки. Виконавці беруться за завдання будь-якого напрямку та складності. Вони завіряють: «Мы решаем самые сложные задачи. Для нашего отдела научных проектов нет нерешаемых задач. Мы реализуем проект абсолютно любой сложности! Возможно, Вы хотите публиковаться в журналах 1 квартиля, входящих в Web of Science? Или Вам нужен индекс Хирша больше, чем у Энштейна? Сотрудничая с нами, "невозможно" превращается в “уже готово”!» [13]. Вочевидь, мова йде про «журнали-хижаки», як їх називають деякі зарубіжні дослідники плагіату. Такі журнали підривають авторитет науки [3].

I таких «умільців» від науки сьогодні чимало. Постає логічне запитання: «Чи можливо цей процес комерціалізації науки подолати закликами до моральності вченого та перевіркою робіт на плагіат?» На мою думку ні. Заклики не будуть почуті, а щодо перевірки, то вже існує ціла низка програм, яка більш-менш успішно дозволяє завуалювати сплагіатовані тексти. Для використання цих засобів достатньо зайти в Google i задати пошук відповідного контенту. Наприклад: «Бесплатные онлайн сервисы для уникализации текстов». Ви неодмінно отримаєте потрібний вам інструмент подолання перевірки по системах антиплагіату. I далі йде детальне роз'яснення, як потрібно працювати із вказаними сайтами [14].

Таким чином, вочевидь, «викорінити» плагіат лише боротьбою із ним засобами його виявлення та перевірки текстів на наявність списування у них навряд чи вдасться.

Українці перехідного постколоніального періоду не одинокі у своїх труднощах і негараздах, у тому числі і у проблемах наявності академічного плагіату та завданнях боротьби із ним. Фактично, «хвороба» тотального списування, тобто, крадіжки чужих текстів та ідей охопила більшість пострадянських країн. Сьогодні пишуться навіть підручники для аспірантів та докторантів з приводу того, як повинен поводитись пошукувач під час підготовки наукової кваліфікаційної роботи. Головним лейтмотивом подібних праць $є$ переконування молодих науковців уникати плагіату. Зокрема, у підручникові 2017 року «История и философия науки. Учебник для аспирантов и соискателей» за редакцією М. А. Ескандерова та А.Н. Чумакова, виданому у Росії, чимало сторінок присвячено проблемі плагіату. Зокрема, стверджується, що філософію, особливо сучасну, постійно стрясають повідомлення про існуючий плагіат [15]. Молодих пошукувачів вчених ступенів переконують, що «вчений не просто високо цінує істину, він прагне зробити свій особистий внесок в її поглиблення. Орієнтація на нове знання закріплюється в категоричній забороні на плагіат. Плагіат вважається в науковому середовищі і у самоусвідомленні науки абсолютно неприпустимим гріхом, який автоматично позбавляє людину права називатись вченим». I після такої категоричної заяви йде зізнання, яке фактично нівелює вище наведені слова. «Світ науки постійно стрясають явні та навіть пред'явлені заднім числом повідомлення про плагіат» [15]. На спеціальну увагу тут заслуговують слова «постійно стрясають...». Якщо відбувається «постійне стрясіння», то, певно, все ж немає «категоричної заборони на плагі- 
ат» у теперішній науці. Далі автори підручника наводять відомий випадок iз провідним генним інженером з Південної Кореї Хван Ву Суком, який був покараний за фальсифікації та плагіат позбавленням професорського звання, роботи та отриманням тюремного строку. Вочевидь, автори хотіли показати, як потрібно карати псевдо вчених, до яких вони однозначно відносять і плагіаторів. Більше того, стверджується, що «відношення до плагіату є індикатором того, наскільки людина, яка займається наукою, відповідає канону вченого і наскільки адекватною є атмосфера наукового співтовариства». Питання правомірності чи ні запозичень, «... культурі посилань на попередників та низка інших, пов'язаних із авторством аспектів $\epsilon$ одним із хворобливих та постійно обговорюваних питань у науковому середовищі...». I далі автори визнають, що проблема наукового плагіату $\epsilon$ не лише складною, але й «заразною» (iз тексту - I.Г.). Із чим потрібно однозначно погодитись, то це із думкою про те, що «боротьба із плагіатом вийшла за внутрішні рамки наукової спільноти та стала злободенною суспільною проблемою; плагіат в науці сьогодні вже став індикатором не тільки наукової добросовісності, але і людської чесності» [15].

Автори даного підручника пропонують навіть ділити вчених за критеріями відношення до фальсифікацій та плагіату на справжніх вчених, яких вони називають «доброякісними вченими», та просто людей, які займають посади науковців. Науковця за посадою автори характеризують як функціональну соціально-рольову одиницю системи, що описується соціологічним поняттям «науковець», тобто той, хто професійно зайнятий у сфері науки з офіційно підтвердженою кваліфікацією та відповідною посадою. А от справжній «доброякісний вчений» повинен відповідати не лише вище вказаним кваліфікаційним та посадовим характеристикам, а самій суті процесу отримання нового наукового знання, зі сто відсотковою установкою несприйняття псевдо наукових «відкриттів», фальсифікацій та плагіату. Якщо подивитись тверезо на виписані розмисли у вище вказаному підручникові для майбутніх офіційно завірених докторів наук, то просто напрошується висновок про абсолютно правильні, але й значною мірою утопічні вимоги авторів даної роботи щодо можливості вирішити задачу подолання плагіатування подібними поясненнями та закликами. Життя завжди набагато складніше і багатогранніше. I у випадку із даною проблемою також. Насамперед, ще й на сьогодні немає однозначного тлумачення поняття «плагіат» як системного соціального феномена нашої доби, що вказує, зокрема, на складність проблеми. Це доводить, зокрема, приклад iз Ньютоном та Лейбніцем (він наводиться у підручникові), які могли із повним правом один одного звинувачувати у плагіаті, проте, історія розсудила інакше. У теперішньому світі суперечка між двома видатними вченими розцінюється не як приклад плагіату, а як факт існування явища конгеніальності. I у кожному резонансному і однозначно не підтвердженому випадкові із плагіатом потрібно і такий момент, як існування феномена конгеніальності, мати на увазі.

Принаймні, українське законодавство враховує специфіку творчого процесу. «Щоб звинуватити автора у плагіаті, необхідно довести, що він мав доступ до оригінального твору та $є$ достатні підстави й дані вважати знов створений твір плагіатом,- зазначає Т. Коваленко, аналізуючи 
українське законодавство у питаннях плагіату та захисту авторського права. - Якщо звинувачений створив схожий твір зовсім випадково, ніколи не бачивши оригінального твору, факту плагіату немає» $[12,36]$.

Взагалі ж, якщо підійти філософсько-світоглядно до проблеми існування феномена плагіату у науці, то виявиться, що все ще складніше, ніж уявляється на перший погляд. Наприклад, як стверджує один із найталановитіших філософів XX століття Мераб Мамардашвілі у своїх знаменитих «Картезіанських розмислах», згідно із філософським вченням Рене Декарта (а саме з Р. Декарта, як відомо, виростає вся сучасна система наукового пізнання), плагіат взагалі неможливий, бо «...коли акт філософського мислення виконаний, то у ньому $є$ все і не може навіть йти мова про якісь запозичення чи плагіат» $[16,80]$. М. Мамардашвілі, вказує. що подібні думки притаманні великій кількості філософів і не стосуються лише декартівської позиції. Адже «...справа в тому, що інакше і не може бути, згідно просто із законом мислення. $\mathcal{E}$ закон мислення щодо філософських текстів - його можна виразити приблизно так: ми здатні зрозуміти те, що написано у філософському тексті, лише у тому випадку, якщо зможемо відтворити те, що у ньому сказано (не слова, а сказане у ньому) як можливість нашого власного мислення - у тому розумінні, що і ми також це помислили»,- каже М. Мамардашвілі $[16,79]$. I далі: «А якщо ми відтворимо дещо сказане чи написане так, що при цьому дійсно зможемо це помислити, то виявиться, що у помисленому колись, якщо ми це відтворили зараз і дійсно мислимо, фактично міститься все. Повторюю, якщо ми дійсно помислили якусь думку, наприклад, Декарта, то виявиться, що це думка і Сократа, і Платона, і Вітгенштейна, і Гуссерля (виділ. авт. I.Г.). Тобто, закон полягає у тому, що, якщо хтось колись виконав акт філософського мислення, то у ньому є все, що взагалі буває у філософському мисленні. У цьому сенсі у філософії немає нічого нового, ніяких винаходів. Бо ми можемо або мислити, або не мислити, але коли мислимо, то мислимо те, що вже помислено. I тому Декарт буде схожий на Канта. Кант буде схожий на Сократа тощо» $[16,80]$. I як тоді бути із плагіатом ідей? Як ставитись, наприклад, до повідомлень наступного типу: «У 9 з 11 філософських дисертацій виявлений плагіат,- дослідження»? [17]

Адже ні Мераба Мамардашвілі, ні тим більше Рене Декарта не запідозриш у захисті плагіаторів та відстоюванні прав псевдонауковців. Вочевидь, питання щодо коренів та сутності плагіату виявляється настільки складним, що потребує й подальших зусиль щодо його вивчення. На сьогодні, вочевидь, доцільно зупинитись на тому простому і прозорому визначенні плагіату, який існує в Законі України «Про авторське право та суміжні права» (стаття 50), - «плагіат - оприлюднення (опублікування), повністю або частково, чужого твору під іменем особи, яка не є автором цього твору» [7].

«Шо стосується загальної системи запобігання та виявлення академічного плагіату в наукових роботах студентів і вчених, то, як свідчить зарубіжна практика, по-перше, слід на рівні держави визнати плагіат фактором занепаду освіти, науки і соціальної свідомості. По-друге, необхідно зрушити з місця призупинений процес створення Національного агентства із забезпечення якості вищої освіти. По-третє, вжити заходів щодо приєднання України (в якомога стислі терміни) до Європейської асоціації за- 
безпечення якості вищої освіти. По-четверте, почати формування недержавної системи забезпечення якості освіти (шляхом створення незалежних агентств оцінювання та забезпечення якості вищої освіти та інших установ, орієнтованих на якість вітчизняної освіти). По-п'яте, законодавчо визначити і закріпити Порядок акредитації незалежних агентств оцінювання та забезпечення якості вищої освіти» $[9,11],-$ пропонують дослідники проблеми академічного плагіату в сучасній Україні, і з цими пропозиціями варто погодитись.

\section{Висновки}

У сучасній Україні проблема існування академічного плагіату є однією зі складових системної кризи української науки та проявом ерозії світоглядно-ціннісних установок спільноти загалом. Усталення олігархічно-кланової держави в Україні не дозволило їй успішно та швидко подолати перехідний постколоніальний період власного розвитку, як то сталося із Прибалтійськими країнами - колишніми радянськими республіками. Негативні тенденції у суспільному розвиткові країни не вдалось подолати навіть шляхом трьох революцій, які Україна пережила за період новітньої незалежності. Наростання соціальної несправедливості у соціумі призвело до вибуху Революції Гідності, зверх завданням якої й було подолання усіх форм і проявів негативу у розвиткові українського соціуму, криза якого досягла таких масштабів, що ставила під питання здатність цього соціуму до незалежного самостійного існування в межах окремої держави.

У контексті вище сказаного варто розглядати і феномен академічного плагіату в українській науці як один із руйнівних факторів суспільного життя. Варто визнати, що на сьогоднішній день в Україні вже є державна політика, спрямована на подолання цього ганебного явища. Із плагіатом безумовно потрібно боротись, бо це корозія науки як системного суспільного явища. Толерування цього феномена $є$ вкрай непорядним із моральноетичної точки зору щодо конкретного науковця та його праці. Говорячи побутовою мовою - це різновид грабунку, отже так само підлягає моральному осудові та правовому покаранню. Але плагіат як явище соціальне був і буде вічним, принаймні у осяжному для нас часі, оскільки це явище породжується у наш час широкою комерціалізацією наукового знання, що $є$ характеристикою науки в добу капіталізму. I тут неможливо не погодитись із думкою історика Ю.Н. Харарі про те, що можна мріяти про безкорисливе прагнення до пізнання, але наука буде тільки тоді справжньою наукою, коли вона достойно чи принаймні більш-менш пристойно фінансуватиметься. А капіталізація науки тягне за собою потребу показувати реальні досягнення, які приносять зиск. Як не парадоксально звучить, одним із засобів боротьби із плагіатом в науці, принаймні на пострадянському просторі, коли трансформації йдуть і у науковій сфері зі значними перекосами та залишками радянської доби (адже не тільки ЖКХ ще залишається в Україні значною мірою реально радянським, але великою мірою і наукові структури та спосіб організації науки теж), $є$ зниження її престижності як маркеру кар'єрної та життєвої успішності. Адже тоді і попит на отримання наукових ступенів для осіб поза науковим середовищем буде 
значно меншим. 3 іншого ж боку, зниження статусу науки як соціального інституту держави буде відкидати країну на маргінес сучасного цивілізованого світу; знижатиме приплив талановитої перспективної молоді, і таким чином стимулюватиме занепад науки в країні. Це небезпечно як для країни, так і для науки. Подолання постколоніального періоду в Україні як перехідного полягає і у створенні нової системи організації науки та нарешті і тут подолання періоду «первісного» дикого капіталізму.

Проблема плагіату є не такою простою, як здається на перший погляд. У кожному окремому випадку потрібно застосовувати індивідуальний підхід до аналізу роботи науковця та виявлених фактів «інтелектуального мародерства». При підтвердженні наявності факту переписування чужого тексту покарання за це має бути достатньо суворим, щоб слугувати попередженням для усіх охочих скористатися результатами чужої праці та для того, щоб раз і назавжди відбити охоту до крадіжки чужого тексту чи ідей у певного науковця. Проте, виробляючи державну політику щодо авторського права та боротьби із його порушеннями, у тому числі і шляхом плагіатування, варто мати на увазі, що плагіат потрібно розглядати не лише як етико-моральну проблему, але як і феномен соціальний, у формуванні та поширенні якого не останню роль відіграють конс'юмеристські настрої у соціумах. Ідеологія боротьби із таким ганебним явищем повинна враховувати і необхідність роботи із масовою свідомістю як представників науки, так і суспільства загалом. В українському варіанті цілеспрямоване загальне оздоровлення соціального організму означатиме, зокрема, і подолання постколоніального періоду із його плинними ідеологіями та неусталеними світоглядними орієнтирами та переходом України до побудови справді цивілізованого справедливого суспільства.

\section{Література}

[1] Скандал із плагіатом Дмитра Дроздовського набирає обертів. 2018. http://litakcent.com/2018/09/27/skandal-iz-plagiatom-dmitra-drozdovskogo-nabiraye-obertiv.

[2] Dhammi, Ish Kumar and Haq, Rehan Ul. 2016. What is plagiarism and how to avoid it? Indian Jornal of Orthopaedics. https://www.ncbi.nlm. nih.gov/pmc/articles/PMC5122250/.

[3] Abad-García, MF. 2019. Plagiarism and predatory journals: A threat to scientific integrity. Anales de Pediatría (English Edition). Vol. 90, Issue 1, January. https://www.sciencedirect.com/science/article/pii/ S2341287918302138.

[4] Корнієнко, Н. 2014. Імітація і плагіат як загроза академічній свободі. Філософсъка думка, 4:101-109.

[5] Плагіат 2018. Вiкineдiя. https://uk.wikipedia.org/wiki/\%D0\%9F\%D0\% BB\%D0\%B0\%D0\%B3\%D1\%96\%D0\%B0\%D1\%82.

[6] Присяжна, Л., Гриценко, Н. 2017. Політика України щодо плагіату. http://www.nbuviap.gov.ua/index.php?option=com_content\&view $=$ article\&id=1674:politika-ukrajini-shchodo-plagiatu\&catid $=8 \&$ Itemid $=350$.

[7] Закон України «Про авторське право і суміжні права», редакція від 04.11.2018, ст 50. Порушення авторського права і суміжних прав. Документ 3792-XII. https://zakon.rada.gov.ua/laws/show/3792-12. 
[8] Хома, О. 2018. Ефективний опір науковця за умов морального розпаду наукових спільнот. Філософсъка думка, 1:47-51.

[9] Касаткін, Д. Ю., Касаткіна, О. М. 2017. Глава 1. Інформаційні технології та програмні засоби вирішення проблеми плагіату в освітній та науково-дослідницькій діяльності ВНЗ, у Перспективные достижения современных ученых: образование и воспитание, физическое воспитание и спорт, философия, литература и лингвистика, культура и искусство, юриспрудениия. : монографія. (Одесса: КУПРИEHKO CB), 6-28.

[10] Харарі, Ю. Н. 2018. Людина розумна. Історія людства від минулого до майбутнъого. Харків, Клуб сімейного дозвілля

[11] Грабовская, И. Н., Талько, Т. Н. 2018. Роль антикоррупционных практик гражданского общества в преодолении кризиса украинской вузовской и академической науки, в Кадравая $i$ антыкарупцыйная палітыка як фактары развіция грамадзянскай супольнасці: зборнік навуковых прач Міжнар. навук.-практ. канф., Магілёў, 24-25 мал 2018 года. (Магілёў: МДУХ), 147-151.

[12] Коваленко, Т. Плагіат: види та відповідальність. 2014. Теорія i npaктика інтелектуальної власності, 4:35-40.

[13] Научные публикации - Publ.Science. 2018. http://publ.science/ru/why.

[14] Бесплатные онлайн сервисы для уникализации текстов. 2018. https:// www.google.com.ua/search?q=\%D1\%83\%D0\%BD\%D0\%B8\%D0\%BA $\%$ D0\%B0\%D0\%BB\%D0\%B8\%D0\%B7\%D0\%B0\%D1\%86\%D0\%B8\%D1 $\% 8 \mathrm{~F}+\% \mathrm{D} 1 \% 82 \% \mathrm{D} 0 \% \mathrm{~B} 5 \% \mathrm{D} 0 \% \mathrm{BA} \% \mathrm{D} 1 \% 81 \% \mathrm{D} 1 \% 82 \% \mathrm{D} 0 \% \mathrm{~B} 0+\% \mathrm{D} 0$ $\%$ BE\%D0\%BD\%D0\%BB\%D0\%B0\%D0\%B9\%D0\%BD\&sa=X\&ved= 2ahUKEwjg0N3A4ZjhAhWbxcQBHdApAa44ChDVAigHegQIChAI\& $\mathrm{biw}=1366 \& \mathrm{bih}=640$.

[15] История и философия науки. Учебник для аспирантов и соискателей. 2017. Страницы о плагиате. https://books.google.com.ua/books? $\mathrm{id}=\mathrm{uKdCDwAAQBAJ \& pg}=\mathrm{PT} 119 \& \mathrm{lpg}=\mathrm{PT} 119 \& \mathrm{dq}=$ философы $+\mathrm{o}+$ плагиате\&source $=$ bl\&ots $=$ V-UQwaJruE\&si.

[16] Мамардашвили, М. 1993. Картезианские размышления. Москва, Издательская группа «Прогесс»; «Культура».

[17] Издание «Комментарии». 2017. В 9 из 11 философских диссертаций обнаружен плагиат (исследование). https://comments.ua/politics/ 608373-v-9-11-filosofskih-dissertatsiy.html.

\section{References}

[1] Skandal iz plagiatom Dmytra Drozdovs'kogo nabyraye obertiv. 2018. http: //litakcent.com/2018/09/27/skandal-iz-plagiatom-dmitra-drozdovskogo-nabiraye-obertiv/.

[2] Dhammi, Ish Kumar and Haq, Rehan Ul. 2016. What is plagiarism and how to avoid it? Indian Jornal of Orthopaedics. https://www.ncbi.nlm. nih.gov/pmc/articles/PMC5122250.

[3] Abad-García, MF. 2019. Plagiarism and predatory journals: A threat to scientific integrity. Anales de Pediatría (English Edition). Vol. 90, Issue 1. https://www.sciencedirect.com/science/article/pii/S2341287918302138. 
[4] Korniyenko, N. 2014. Imitaciya i plagiat yak zagroza akademichnij svobodi. Filosofs' $k a$ dumka, 4:101-109.

[5] Plagiat 2018. Vikipediya. URL: https://uk.wikipedia.org/wiki/\%D0\%9F\% D0\%BB\%D0\%B0\%D0\%B3\%D1\%96\%D0\%B0\%D1\%82.

[6] Prysyazhna, L., Grycenko, N. 2017. Polityka Ukrayiny shhodo plagiatu. URL: http://www.nbuviap.gov.ua/index.php?option=com_content\&view= article\&id=1674:politika-ukrajini-shchodo-plagiatu\&catid $=8 \&$ Itemid $=350$.

[7] Zakon Ukrayiny «Pro avtors'ke pravo i sumizhni prava», redakciya vid 04.11.2018, st 50. Porushennya avtors'kogo prava i sumizhnyx prav. Dokument 3792-XII. https://zakon.rada.gov.ua/laws/show/3792-12.

[8] Xoma, O. 2018. Efektyvnyj opir naukovcya za umov moral'nogo rozpadu naukovyx spil'not. Filosofs' $k a$ dumka, 1:47-51.

[9] Kasatkin, D. Yu., Kasatkina, O. M. 2017. Glava 1. Informacijni texnologiyi ta programni zasoby vyrishennya problemy plagiatu v osvitnij ta naukovodoslidnycz'kij diyal'nosti VNZ. Perspektyvnue dostyzhenyya sovremennux uchenux: obrazovanye y vospytanye, fyzycheskoe vospytanye y sport, fylosofyya, lyteratura y lyngvystyka, kul'tura y yskusstvo, yurysprudencyya: monografiya. (Odessa: KUPRY'ENKO SV), 6-28.

[10] Xarari, Yu. N. 2018. Lyudyna rozumna. Istoriya lyudstva vid mynulogo do majbutn'ogo. Xarkiv, Klub simejnogo dozvillya.

[11] Grabovskaja, I. N., Tal'ko, T. N. 2018. Rol' antikorrupcionnyh praktik grazhdanskogo obshhestva $\mathrm{v}$ preodolenii krizisa ukrainskoj vuzovskoj i akademicheskoj nauki. Kadravaja i antykarupcyjnaja palityka jak faktary razviccja gramadzjanskaj supol'nasci: zbornik navukovyh prac Mizhnar. navuk.-prakt. kanf., Magiljow, 24-25 maja 2018 goda. (Magiljow: MDUH), 47-151.

[12] Kovalenko, T. Plagiat: vydy ta vidpovidal'nist'. (2014). Teoriya i praktyka intelektual'noyi vlasnosti, 4:35-40.

[13] Nauchnye publikacii - Publ.Science. 2018. URL: http://publ.science/ru/ why.

[14] Besplatnye onlajn servisy dlja unikalizacii tekstov. 2018. URL: https:// www.google.com.ua/search?q=\%D1\%83\%D0\%BD\%D0\%B8\%D0\%BA \%D0\%B0\%D0\%BB\%D0\%B8\%D0\%B7\%D0\%B0\%D1\%86\%D0\%B8 $\% \mathrm{D} 1 \% 8 \mathrm{~F}+\% \mathrm{D} 1 \% 82 \% \mathrm{D} 0 \% \mathrm{~B} 5 \% \mathrm{D} 0 \% \mathrm{BA} \% \mathrm{D} 1 \% 81 \% \mathrm{D} 1 \% 82 \% \mathrm{D} 0 \% \mathrm{~B} 0$ +\%D0\%BE\%D0\%BD\%D0\%BB\%D0\%B0\%D0\%B9\%D0\%BD\&sa=X\& ved=2ahUKEwjg0N3A4ZjhAhWbxcQBHdApAa44ChDVAigHegQICh$\mathrm{AI} \& \mathrm{biw}=1366 \& \mathrm{bih}=640$.

[15] Istorija $i$ filosofija nauki. Uchebnik dlja aspirantov i soiskatelej. 2017. Stranicy o plagiate. URL: https://books.google.com.ua/books?id=uKdCDwAAQBAJ\&pg $=$ PT119\&lpg $=$ PT119\&dq $=$ философы + o + плагиате $\&$ source $=$ bl\&ots $=$ V-UQwaJruE\&si.

[16] Mamardashvili, M. 1993. Kartezianskie razmyshlenija. Moskva, Izdatel'skaja gruppa «Progess»; «Kul'tura».

[17] Izdanie «Kommentarii». 2017. V 9 iz 11 filosofskih dissertacij obnaruzhen plagiat (issledovanie). URL: https://comments.ua/politics/608373-v-911-filosofskih-dissertatsiy.html. 